\title{
BMJ Open Retrospective study using MRI to measure depths of acupuncture points in neck and shoulder region
}

\author{
Pei-Chi Chou, ${ }^{1,2}$ Yu-Chuen Huang, ${ }^{1,3}$ Chun-Jen Hsueh, ${ }^{4,5}$ Jaung-Geng Lin, ${ }^{1}$ \\ Heng-Yi Chu ${ }^{5}$
}

To cite: Chou P-C,

Huang Y-C, Hsueh C-J, et al. Retrospective study using MRI to measure depths of acupuncture points in neck and shoulder region. BMJ Open 2015;5:e007819. doi:10.1136/bmjopen-2015007819

- Prepublication history for this paper is available online. To view these files please visit the journal online (http://dx.doi.org/10.1136/ bmjopen-2015-007819).

Received 29 January 2015 Revised 2 June 2015 Accepted 30 June 2015

CrossMark

\footnotetext{
${ }^{1}$ School of Chinese Medicine, College of Chinese Medicine, China Medical University, Taichung, Taiwan

${ }^{2}$ Department of Traditional Chinese Medicine, China Medical University Hospital Eastern Branch, Taichung,

Taiwan

${ }^{3}$ Department of Medical Research, China Medical University Hospital, Taichung, Taiwan

${ }^{4}$ Department of Medical Imaging, Changhua Christian Hospital, Changhua, Taiwan ${ }^{5}$ Department of Physical Medicine and Rehabilitation, Tri-Service General Hospital, National Defense Medical Center, Taipei, Taiwan
}

Correspondence to Dr Heng-Yi Chu; hyichu@yahoo.com.tw

\section{ABSTRACT}

Objectives: There are safety issues associated with acupuncture treatment. Previous studies regarding needling depth of acupuncture points revealed inconsistent results due to vague depth definition, acupuncture point localisation and measuring tools. The objective of this study is to find and compare the differences of the mean depths of 11 acupuncture points in the neck and shoulder region between subjects, with variables including gender and body mass index (BMI).

Setting: This study was conducted at a single medical center in Taiwan.

Participants: Three hundred and ninety-four participants were included in this study. Participants were grouped according to gender and BMI. Acupuncture points were localised by WHO standard and measured by MRI.

Outcome measures: The distance from the needle insertion point (surface of the skin) to any tissues that would cause possible/severe complications.

Results: Mean depths of 11 points were obtained in groups of different BMI and gender. Mean depths of all participants regardless of BMI and gender are as follows, in centimetres: GB21=5.6, SI14=5.2, SI15=8.8, GV15=4.9, GV16=4.6, GB20=5.0, ST9=1.6, SI16=1.8, $\mathrm{SI} 17=2.4, \mathrm{TE} 16=3.1, \mathrm{LI} 18=1.3$. Participants with higher BMI had greater measured depths in both gender groups. Male participants had larger mean depths than female participants regardless of BMI except in SI17 and LI18. When taking BMI into consideration, depths in male participants are greater than in female participants in most of the points except the following: GB21, TE16 in obesity group; ST9 in underweight and obesity group; SI16 in ideal body weight, overweight and obesity group; SI17, LI18 in each group.

Conclusions: Participants with higher BMI had greater measured depths and males tended to have greater depths in most of the points. Clinical practitioners are recommended to consider this information to prevent complications when applying acupuncture treatment to their patients.

\section{INTRODUCTION}

Acupuncture has generally been regarded as a relatively safe therapy method by many

\section{Strengths and limitations of this study}

- This is the first study to investigate the depths of acupuncture points in neck and shoulder regions using MRI.

- Acupuncture points were localised by WHO standards.

- This study consists of the most participants among similar existing studies regarding measuring depths of acupoints.

- We were unable to analyse variables other than gender and body mass index that may affect needling depth, such as age, diagnosis, neck girth and side difference.

practitioners of complementary and alternative medicine as well as by most patients, as Witt et $a l^{1}$ reported. White et $a l^{2}$ metaanalysed reports of adverse effects associated with acupuncture and concluded that the risk of serious events occurring in association with acupuncture is very low. However, numerous risks associated with this treatment method still exist, and some of them could be clinically serious problems. Therefore, we should pay more attention to the safety issues of acupuncture treatment. ${ }^{3}$

Ancient Chinese classics and historical texts such as Huangdi Neijing have documented the adverse effects of acupuncture. For example, deep insertion at the acupuncture point Qupen (ST12) may cause dyspnoea, cough and, possibly, collapse of the lung.

Most of the reported adverse events were minor complications such as needling pain, cutaneous disorders, haematoma, hypotension, nausea, vomiting and fainting. ${ }^{1}$ McPherson reported that a range of 'negative' reactions including tiredness and drowsiness were frequently reported, ${ }^{4}$ but these do not prevent most patients seeking further acupuncture; and acupuncture is a relatively safe intervention when practiced by regulated practitioners. ${ }^{5}$ 


\begin{tabular}{|c|c|}
\hline Trauma & $\begin{array}{l}\text { Penetrating the stomach cavity, }{ }^{6} \text { epidural haematoma, }{ }^{2}{ }^{7-9} \text { pneumothorax, },^{2} 1011312-17 \text { medulla } \\
\text { spinalis injury, }{ }^{16} \text { puncture of liver, }{ }^{3} \text { puncture of heart, }{ }^{318} \text { cardiac tamponade, }{ }^{215}{ }^{19} \text { myositis } \\
\text { ossificans, }{ }^{20} \text { vascular injury, }{ }^{321} \text { popliteal arteriovenous fistula, }{ }^{22} \text { spinal cord trauma, }{ }^{217}{ }^{23} \text { intracranial } \\
\text { hemorrhage, }{ }^{24} \text { lumbar epidural haematoma, }{ }^{25} \text { transverse myelopathy, }{ }^{26} \text { haemothorax, compartment } \\
\text { syndrome arterial injury, deep vein thrombosis, popliteal artery occlusion, pseudoaneurysm, } \\
\text { subarachnoid haemorrhage and medulla trauma, etc. }{ }^{2}\end{array}$ \\
\hline Infection & $\begin{array}{l}\text { Endocarditis, }{ }^{16} \text { multiple epidural abscesses, }{ }^{27} \text { cervical epidural abscess, }{ }^{28}{ }^{29} \text { paraplaegia caused by } \\
\text { spinal infection, }{ }^{30} \text { septic arthritis, }{ }^{231} \text { cervical subdural empyema, }{ }^{32} \text { hepatitis and contact } \\
\text { dermatitis, }{ }^{14}{ }^{17} \text { skin infection, }{ }^{5} \text { chronic inflammatory granuloma, }{ }^{33} \text { bacterial meningitis, }{ }^{25}\end{array}$ \\
\hline $\begin{array}{l}\text { Miscellaneous } \\
\text { events }\end{array}$ & $\begin{array}{l}\text { Hypotension, nausea, vomiting and fainting, }{ }^{3} \text { death, }{ }^{316}{ }^{34} \text { severe asthma, }{ }^{16} \text { tiredness, drowsiness, }^{\text {pese }} \\
\text { pain, severe headache or migraine, severe sleeplessness, diarrhoea, etc. }\end{array}$ \\
\hline
\end{tabular}

Complications in acupuncture practice may result from violations of sterile procedure and/or negligence of practitioners. Common adverse events associated with acupuncture treatment are listed in table 1. Some events, specifically trauma and infections, are likely to be avoidable. $^{2}$

Pneumothorax has been reported as the most frequent adverse effect associated with death. However, it is also the most frequent of all serious, nonfatal complications of acupuncture. ${ }^{14}$ Injuries to organs and tissues, or even death, would have been avoidable with a better understanding of the sufficient anatomical knowledge and appropriate depth of needle insertion, especially in points of higher needling frequency.

As many mentioned, injuries of lung, heart, nerves and vessels occur in the points scattered in the neck and shoulder regions. In this study, we focused on the investigation of 11 points with the depths actually measured on MRI in these areas. They are GV15(Yamen), GV16(Fengfu), GB20(Fengchi), GB21(Jianjing), SI14(Jianwaishu), SI15 (Jianzhongshu), SI16(Tianchuang), SI17(Tianrong), TE16(Tianyou), ST9(Renying) and LI18(Futu).

We would also like to understand how some variables such as body size and gender would affect the measured depth of each point, so we used body mass index (BMI) as the guide for grouping of participants in the current study.

Most of the previously conducted studies regarding acupuncture needling depth used CT as the measuring tool. ${ }^{35}$ In this investigation, we used MRI as a measuring tool due to its excellent soft tissue contrast and multiplanar imaging capability. ${ }^{36}$ The objective of this study is to find the mean distances from the skin surface to the major organs of 11 acupoints that would cause no harm during the treatment of each point and to compare the differences between participants with variables including gender and BMI.

\section{PARTICIPANTS AND METHODS}

\section{Subjects}

The images of participants aged over 18 years who underwent MRI examination for neck and/or shoulder region that covered the points in this study from 7 June
1999 to 9 April 2014 were collected from the Tri-Service General Hospital, Taipei, Taiwan. This study was approved by the Tri-Service General Hospital, National Defense Medical Center Institutional Review Board.

These participants had undergone MRI to evaluate conditions such as herniated intervertebral discs, compression fracture of cervical vertebrae, degenerative joint diseases and acute conditions such as pain or surgical emergencies, accidental injuries, infections and oncology diseases. Participants with severe clinical condition such as tumour invasion or fractures of the associated region that may have affected the measuring definition or accuracy on MRI were excluded. We also excluded participants whose MRI were not obtained for both sides. Subject data such as gender, age, body length and weight were retrieved from the medical records. Participants were divided into four groups according to BMI: underweight $(\mathrm{BMI}<18.5)$, ideal bodyweight $(\mathrm{BMI}=18.5-22.9)$, overweight $(\mathrm{BMI}=23-24.9)$ and obesity $(\mathrm{BMI} \geqq 25) .{ }^{37}$

\section{Methods}

As terms such as safe needling depth or dangerous needling depth are very confusing due to lack of unanimous agreement between investigators, we define the term of depth as the distance measured from the surface of the skin of the acupoint to the adventitia of major vessels (such as internal jugular vein/artery and common carotid artery for GB20,SI17, TE16, ST9, LI18 and SI16), nerves/spinal cord (such as dura mater for GV15 and 16) or pleural membrane (such as for GB21, SI14 and SI15), accordingly; that is, the distance from the needle insertion point (surface of the skin) to any tissues that would cause possible/severe complications such as haemorrhage (ie, vessels), nerve injury (ie, spinal cord) or organ damage (ie, lung) if punctured.

The needling angle is perpendicular to the surface of the skin of each point. Both sides were measured in every subject except for GV15 and GV16.

The selected acupuncture points in the neck and shoulder region are depicted in figure 1.

The MRI equipment used from 7 June 1999 to 9 April 2014 were the GE Signa EXCITE HDx 1.5 T, GE Signa 
Figure 1 Selected acupuncture points: the 11 selected acupuncture points in the neck and shoulder region.
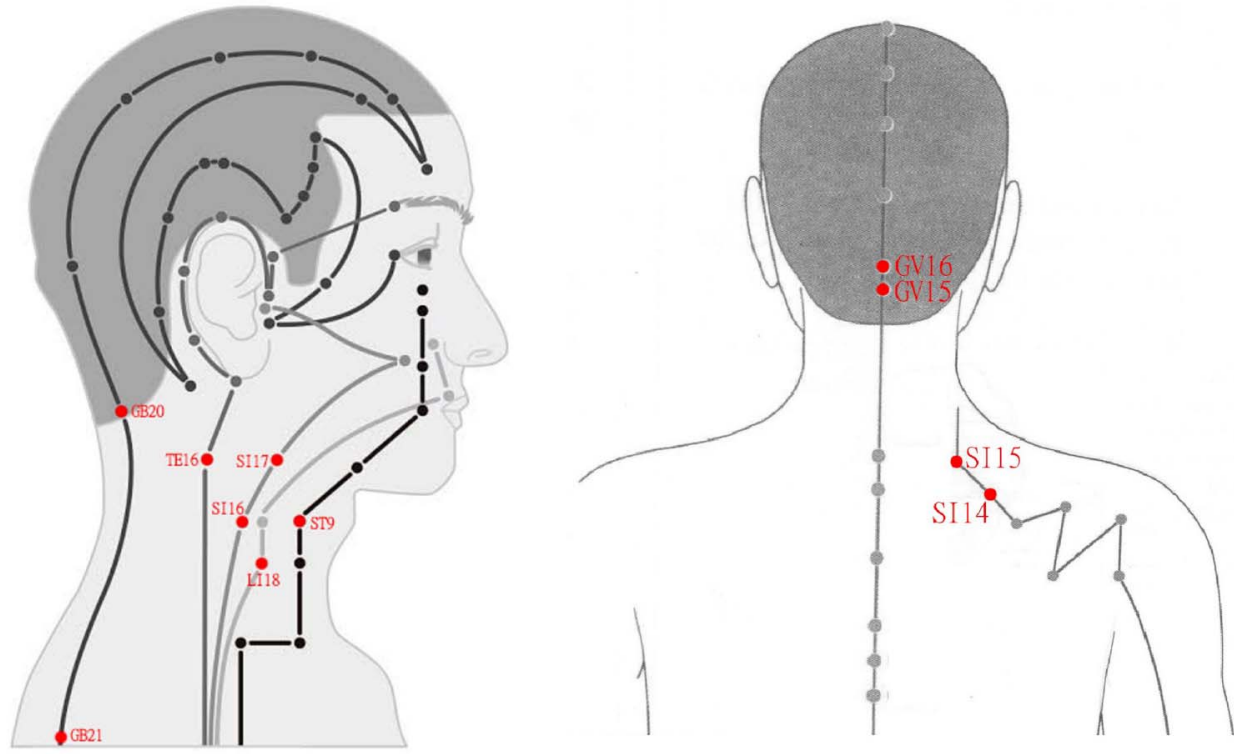

Discovery $7503 \mathrm{~T}$ (General Electric, Fairfield, MRI, USA) and PHILIPS Achieva $1.5 \mathrm{~T}$ (Koninklijke Philips Electronics NV). All MRIs were taken in the sagittal, coronal and axial planes. Neck images were obtained from the occipital level to two sections below the T2-3 vertebrae and the total field of view was about $25 \mathrm{~cm}$. The section thickness between each image was 1.1 to 5-6 mm on each plane. Depth was measured on MRI and displayed on a PACS (Picture Archiving and Communication System; Centricity CSR4, General Electric, Fairfield, CT, USA) system for imaging. One of the authors, who specialised in imaging of neural systems for 15 years, was in charge of the measurement. The localisation of each point was according to suggestions from WHO standard acupuncture locations. ${ }^{38}$

\section{Statistical analysis}

Demographic data of participants were presented as mean \pm SD for continuous variables and percentage for categorical variables. Student's t test was used to determine the differences between the male and female group. Analysis of variance test or Brown-Forsythe test was used to determine the differences among the four BMI groups (underweight, ideal body weight, overweight and obesity group). Simple linear regression was used to predict the depth of needling acupoints by BMI. A p value of $<0.05$ was considered statistically significant. Statistical analyses were carried out using Statistical Package for the Social Sciences software V.18.0 (SPSS Inc, Chicago, Illinois, USA).

\section{RESULTS}

The images of 798 participants were reviewed but only the images of 394 participants were included in this study, with 198 male participants and 196 female subjects. Male participants are taller and heavier than female ones. Mean age and BMI does not differ in two of the groups. There are 88 participants in the underweight group, 102 participants in ideal bodyweight group, 99 participants in overweight group and 105 participants in the obesity group. Details of demographic data are shown in table 2. Mean measured depths of each point among different BMI groups and genders are shown in table 3. Mean measured depths of the 11 acupoints for all participants regardless of BMI and gender are as follows, in centimetres: GB21=5.6, $\mathrm{SI} 14=5.2, \quad \mathrm{SI} 15=8.8, \quad \mathrm{GV} 15=4.9, \quad \mathrm{GV} 16=4.6, \quad \mathrm{~GB} 20=5.0$, ST9=1.6, SI16=1.8, SI17=2.4, TE16=3.1, LI18=1.3. Generally speaking, male participants had larger mean depths than female participants regardless of BMI except in SI17 and LI18. From the perspective of BMI, the participants with greater BMI had larger mean depths, as detailed in table 3 .

BMI is a very significant factor affecting measured depth in every point. The measured depth of every point significantly correlated with the increase in BMI. Depths in male participants are greater than in female participants in most of the points, except the following: GB21, TE16 in obesity group; ST9 in underweight and obesity group; SI16 in ideal body weight, overweight and obesity group; SI17, LI18 in each group. We also show the results of regression analysis on BMI and depth of each acupoint for male and female subjects, respectively, in table 4, for prediction of the mean needling depth. The mean predicted needling depth of each point in male participants tends to be greater than in female subjects.

\section{DISCUSSION}

To our knowledge, this is the first study to investigate the mean depths of acupuncture points in the neck and shoulder regions using MRI, and locating the acupoints according to the standard methods laid out in the WHO guidelines. This study also consists of the most 
Table 2 Demographic data of subjects

\begin{tabular}{|c|c|c|c|c|}
\hline & All & Male & Female & p Value \\
\hline Gender & 394 & $198(50.3 \%)$ & $196(49.8 \%)$ & \\
\hline Age (year, mean $\pm S D)$ & $52.9 \pm 14.1$ & $52.6 \pm 13.1$ & $53.2 \pm 15.0$ & 0.648 \\
\hline Weight (kg, mean+SD) & $60.9 \pm 12.3$ & $64.7 \pm 12.2$ & $57.2 \pm 11.3$ & $<0.001$ \\
\hline Height (cm, mean \pm SD) & $163.5 \pm 8.0$ & $168.6 \pm 6.3$ & $158.3 \pm 5.8$ & $<0.001$ \\
\hline $\mathrm{BMI}\left(\mathrm{kg} / \mathrm{m}^{2}\right.$, mean $\left.\pm \mathrm{SD}\right)$ & $22.7 \pm 4.0$ & $22.7 \pm 3.9$ & $22.8 \pm 4.1$ & 0.848 \\
\hline Underweight (BMI:<18.5) & $88(22.3 \%)$ & $46(23.2 \%)$ & $42(21.4 \%)$ & 0.979 \\
\hline Ideal body weight (BMI:18.5- <23.0) & $102(25.9 \%)$ & $51(25.8 \%)$ & $51(26.0 \%)$ & \\
\hline Overweight (BMI: $23.0-<25.0)$ & $99(25.1 \%)$ & $49(24.7 \%)$ & $50(25.5 \%)$ & \\
\hline Obesity (BMI: $\geq 25.0$ ) & $105(26.6 \%)$ & $52(26.2 \%)$ & $53(27.0 \%)$ & \\
\hline
\end{tabular}

participants among all existing studies regarding needling depth.

Most studies regarding safe/dangerous needling depth of acupuncture points used dissections from cadavers, which may be different from the real situation. ${ }^{35}$ Other investigations used CT scan as the imaging tool for depth measurement. There was great inconsistency among the depths measured by different methods. For example, the suggested safe needling depths for GV16 are $27.73-33.39 \mathrm{~mm}$ (using CT images), $40.08 \mathrm{~mm}$ (using dissected specimens) and 43.46-57.42 mm (using dissected specimens), respectively. ${ }^{35}$ In this study, we selected MRI as the measuring tool. The major advantages of MRI over CT are primarily superior contrast resolution and better soft tissue differentiation. ${ }^{39} 40-42$

The other advantages of MRI are the ability to change the contrast of the images on PACS and the possibility of combining the different imaging planes for better acupuncture point localisation.

We selected points in the neck and shoulder region where some are frequently needled with potential danger during needling. SI14 and SI15 were picked as they are not protected by scapula in the posterior shoulder region. The needling angle and direction also makes GB21 a candidate for lung injury. Although the external jugular vein can be easily dodged by careful inspection of the region close to points such as GB20, SI17, TE16, ST9, LI18 and SI16, major vessels (such as internal jugular vein/artery and common carotid artery) were the main objects to avoid.

There is no unanimous definition of dangerous depth, safe depth or therapeutic depth for acupuncture points. Most of the authors chose $75 \%$ or $80 \%$ of the measured depths from their clinical experience. Moreover, from the clinical experience, most of the points are needled at the angle perpendicular to the skin surface, there is no universal needling angle at each point either, mostly resulting from the complex anatomical structures, respectively. ${ }^{35}$ Different needling angle may actually cause different measured depth at each point.

In this study, we define the depth by documenting the measured distance from the skin surface to major vessels, nerves or any organ, such as lung, under the perpendicular needling angle. We have successfully reviewed and measured the MRI of 394 patients; the mean depth of each point was obtained. We also analysed the variables including BMI and gender, and obtained the corresponding mean depth in each subgroup. Both MRI and gender would affect the measured depth significantly. Regression analysis on BMI and depth of each point for male and female participants was carried out for further reference.

BMI is widely used as an international index for assessment of obesity of adults in Taiwan and other Asian countries. ${ }^{37}$ Its validity makes it a useful tool for comparisons among participants with different body sizes. ${ }^{43} 44$

Only one study used BMI to compare subjects' needling depths. Nearly all parameters (interscapular distance, soft tissue thickness) correlated with the BMI in acupoints BL25 and BL26. ${ }^{45}$

Participants with greater BMI theoretically had more adipose tissue in the body, which results in thicker limbs and broader neck or shoulder girdle. As a result, in this study, participants with greater BMI had greater measured depth in all the points in this investigation. Neck circumference $(\mathrm{NC})$ may play a role in determining needling depth in points around the neck. Ben-Noun et $a l^{46}$ indicated a significant association between $\mathrm{NC}$ and: BMI, age, weight and waist circumference. Onat et $a l^{47}$ suggested that $\mathrm{NC}$ can serve as a useful measure of central obesity, that is, participants with greater BMI may have greater NC, which leads to greater needling depth in the neck region.

With the increase of BMI, lung volume may also be reduced and this probably leads to greater needling depth in the shoulder region, such as in GB21, SI14 and SI15. ${ }^{48}$

Male participants had a larger BMI than female participants in this investigation. Male participants were also heavier and higher, even with the same BMI. In most of the points, regardless of BMI difference, male participants tended to have greater measured depth as compared to female subjects. However, this lacks consistency in points such as ST9, SI16, SI17 and LI18. This fact raises the question: Why is there gender difference in certain points? Sexual dimorphism of body composition 
Table 3 Mean measured depth of each point compared by BMI and gender

\begin{tabular}{|c|c|c|c|c|c|}
\hline Variable & $\begin{array}{l}\text { Underweight } \\
\text { Mean }(95 \% \mathrm{Cl})\end{array}$ & $\begin{array}{l}\text { Ideal body weight } \\
\text { Mean }(95 \% \mathrm{Cl})\end{array}$ & $\begin{array}{l}\text { Overweight } \\
\text { Mean }(95 \% \mathrm{Cl})\end{array}$ & $\begin{array}{l}\text { Obesity } \\
\text { Mean }(95 \% \mathrm{Cl})\end{array}$ & p Value* \\
\hline \multicolumn{6}{|l|}{ GB21 $(\mathrm{cm})$} \\
\hline All & 3.7 (3.5 to 3.9 ) & 5.1 (4.9 to 5.3 ) & 6.1 (5.9 to 6.3 ) & 7.0 (6.8 to 7.3$)$ & $<0.001$ \\
\hline Male & 4.0 (3.7 to 4.3$)$ & 5.3 (5.1 to 5.6$)$ & 6.4 (6.0 to 6.7$)$ & 7.1 (6.8 to 7.5$)$ & $<0.001$ \\
\hline Female & 3.4 (3.1 to 3.6 ) & 4.9 (4.7 to 5.2$)$ & 5.8 (5.6 to 6.0$)$ & 6.9 (6.5 to 7.2$)$ & $<0.001$ \\
\hline p Value† & 0.001 & 0.032 & 0.012 & 0.264 & \\
\hline \multicolumn{6}{|l|}{ SI14 (cm) } \\
\hline All & 3.8 (3.6 to 4.1 ) & 5.0 (4.8 to 5.3$)$ & 5.9 (5.7 to 6.1$)$ & 6.4 (6.1 to 6.8$)$ & $<0.001 \ddagger$ \\
\hline Male & 4.5 (4.1 to 4.9$)$ & 5.7 (5.4 to 6.0$)$ & $6.3(6.0$ to 6.7$)$ & $7.2(6.5$ to 8.0$)$ & $<0.001 \ddagger$ \\
\hline Female & 3.2 (3.0 to 3.4 ) & 4.6 (4.3 to 4.8$)$ & 5.7 (5.4 to 5.9$)$ & 6.1 (5.7 to 6.5 ) & $<0.001 \ddagger$ \\
\hline p Value† & $<0.001$ & $<0.001$ & 0.002 & 0.003 & \\
\hline \multicolumn{6}{|l|}{ SI15 (cm) } \\
\hline All & $7.3(7.0$ to 7.5$)$ & 8.5 (8.3 to 8.7$)$ & 9.0 (8.8 to 9.3 ) & $10.1(9.8$ to 10.4$)$ & $<0.001 \ddagger$ \\
\hline Male & 7.7 (7.3 to 8.1$)$ & 9.2 (8.9 to 9.4$)$ & 9.6 (9.2 to 9.9$)$ & $10.7(10.2$ to 11.1$)$ & $<0.001 \ddagger$ \\
\hline Female & 6.7 (6.6 to 6.9$)$ & $7.9(7.6$ to 8.1$)$ & 8.5 (8.3 to 8.7$)$ & $9.5(9.2$ to 9.9$)$ & $<0.001 \ddagger$ \\
\hline$p$ Value $\dagger$ & $<0.001$ & $<0.001$ & $<0.001$ & $<0.001$ & \\
\hline \multicolumn{6}{|l|}{ GV15 (cm) } \\
\hline All & 3.9 (3.7 to 4.0$)$ & 4.7 (4.6 to 4.9$)$ & 5.3 (5.1 to 5.4$)$ & 5.5 (5.3 to 5.6$)$ & $<0.001 \ddagger$ \\
\hline Male & 4.3 (4.1 to 4.5$)$ & $5.2(5.0$ to 5.4$)$ & 5.5 (5.3 to 5.7$)$ & 5.7 (5.5 to 6.0$)$ & $<0.001$ \\
\hline Female & 3.5 (3.3 to 3.6 ) & $4.2(4.0$ to 4.4$)$ & 5.0 (4.8 to 5.2$)$ & $5.2(5.0$ to 5.4$)$ & $<0.001 \ddagger$ \\
\hline $\mathrm{p}$ Value $†$ & $<0.001$ & $<0.001$ & $<0.001$ & $<0.001$ & \\
\hline \multicolumn{6}{|l|}{ GV16 (cm) } \\
\hline All & 3.6 (3.4 to 3.7 ) & 4.6 (4.4 to 4.7$)$ & 4.8 (4.7 to 5.0$)$ & $5.2(5.1$ to 5.4$)$ & $<0.001 \ddagger$ \\
\hline Male & 4.0 (3.8 to 4.1$)$ & 4.9 (4.7 to 5.2$)$ & 5.1 (5.0 to 5.3$)$ & 5.5 (5.3 to 5.6$)$ & $<0.001 \ddagger$ \\
\hline Female & 3.1 (2.9 to 3.3 ) & $4.2(4.0$ to 4.4$)$ & 4.6 (4.4 to 4.7$)$ & 5.0 (4.8 to 5.2$)$ & $<0.001 \ddagger$ \\
\hline$p$ Value $\dagger$ & $<0.001$ & $<0.001$ & $<0.001$ & 0.001 & \\
\hline \multicolumn{6}{|l|}{ GB20 (cm) } \\
\hline All & 4.3 (4.1 to 4.5$)$ & 4.8 (4.6 to 5.0 ) & 5.1 (5.0 to 5.2 ) & 5.6 (5.4 to 5.7$)$ & $<0.001 \ddagger$ \\
\hline Male & 4.8 (4.6 to 5.0$)$ & $5.2(4.9$ to 5.4$)$ & 5.3 (5.1 to 5.5 ) & 5.9 (5.7 to 6.1$)$ & $<0.001 \ddagger$ \\
\hline Female & 3.7 (3.6 to 3.9$)$ & 4.5 (4.3 to 4.6$)$ & $4.9(4.8$ to 5.1$)$ & 5.3 (5.1 to 5.5$)$ & $<0.001 \ddagger$ \\
\hline p Value $†$ & $<0.001$ & $<0.001$ & $<0.001$ & $<0.001$ & \\
\hline \multicolumn{6}{|l|}{ ST9 (cm) } \\
\hline All & $1.2(1.1$ to 1.3$)$ & $1.6(1.5$ to 1.7$)$ & 1.7 (1.7 to 1.8$)$ & 1.9 (1.8 to 2.0$)$ & $<0.001 \ddagger$ \\
\hline Male & $1.3(1.1$ to 1.4$)$ & $1.7(1.6$ to 1.8$)$ & 1.9 (1.8 to 2.0$)$ & $1.9(1.8$ to 2.0$)$ & $<0.001 \ddagger$ \\
\hline Female & $1.2(1.1$ to 1.3$)$ & $1.4(1.3$ to 1.5$)$ & 1.6 (1.5 to 1.7$)$ & 1.9 (1.8 to 2.0$)$ & $<0.001 \ddagger$ \\
\hline p Value $†$ & 0.157 & 0.001 & $<0.001$ & 0.996 & \\
\hline \multicolumn{6}{|l|}{ SI16 (cm) } \\
\hline All & 1.5 (1.4 to 1.6$)$ & 1.7 (1.6 to 1.8$)$ & 2.0 (1.9 to 2.1$)$ & 2.1 (2.0 to 2.2 ) & $<0.001$ \\
\hline Male & $1.6(1.5$ to 1.8$)$ & 1.8 (1.7 to 1.9$)$ & 2.0 (1.8 to 2.1$)$ & 2.1 (2.0 to 2.3 ) & $<0.001$ \\
\hline Female & $1.4(1.3$ to 1.5$)$ & $1.6(1.5$ to 1.8$)$ & 1.9 (1.8 to 2.1$)$ & 2.0 (1.9 to 2.2$)$ & $<0.001$ \\
\hline p Value & 0.018 & 0.125 & 0.568 & 0.401 & \\
\hline \multicolumn{6}{|l|}{ SI17 $(\mathrm{cm})$} \\
\hline All & 1.8 (1.6 to 1.9$)$ & 2.3 (2.2 to 2.3 ) & 2.6 (2.5 to 2.7$)$ & 2.9 (2.8 to 3.0 ) & $<0.001 \ddagger$ \\
\hline Male & $1.9(1.7$ to 2.1$)$ & 2.2 (2.1 to 2.4 ) & 2.5 (2.4 to 2.7$)$ & 2.9 (2.6 to 3.1$)$ & $<0.001 \ddagger$ \\
\hline Female & $1.6(1.5$ to 1.7$)$ & 2.3 (2.1 to 2.4$)$ & 2.7 (2.5 to 2.8$)$ & $2.9(2.7$ to 3.1$)$ & $<0.001 \ddagger$ \\
\hline $\mathrm{p}$ Value $†$ & 0.013 & 0.949 & 0.153 & 0.560 & \\
\hline \multicolumn{6}{|l|}{ TE16 $(\mathrm{cm})$} \\
\hline All & 2.3 (2.2 to 2.5 ) & 2.9 (2.7 to 3.0$)$ & 3.3 (3.1 to 3.4 ) & 3.8 (3.6 to 4.0 ) & $<0.001 \ddagger$ \\
\hline Male & 2.6 (2.3 to 2.8 ) & $3.2(2.9$ to 3.4$)$ & 3.4 (3.3 to 3.6$)$ & 3.7 (3.4 to 4.0$)$ & $<0.001 \ddagger$ \\
\hline Female & 2.0 (1.9 to 2.2 ) & 2.6 (2.4 to 2.8 ) & 3.1 (2.9 to 3.3 ) & 3.8 (3.5 to 4.1 ) & $<0.001 \ddagger$ \\
\hline $\mathrm{p}$ Value & $<0.001$ & $<0.001$ & 0.028 & 0.595 & \\
\hline \multicolumn{6}{|l|}{ Ll18 (cm) } \\
\hline All & 1.1 (1.0 to 1.1$)$ & 1.2 (1.2 to 1.3$)$ & 1.4 (1.3 to 1.5$)$ & 1.5 (1.4 to 1.5$)$ & $<0.001 \ddagger$ \\
\hline Male & 1.1 (1.0 to 1.2$)$ & $1.3(1.2$ to 1.3$)$ & 1.4 (1.3 to 1.5$)$ & 1.4 (1.3 to 1.5$)$ & $<0.001$ \\
\hline Female & $1.0(0.9$ to 1.1$)$ & $1.2(1.1$ to 1.2$)$ & $1.4(1.3$ to 1.4$)$ & 1.5 (1.4 to 1.6$)$ & $<0.001 \ddagger$ \\
\hline $\mathrm{p}$ Value $\dagger$ & 0.063 & 0.055 & 0.691 & 0.170 & \\
\hline
\end{tabular}

${ }^{*}$ ANOVA test or Brown-Forsythe test: determining the differences among different BMI groups.

†Student's $t$ test: determining the differences between the male and female.

$\ddagger p$ Values were performed by Brown-Forsythe test.

ANOVA, analysis of variance; BMI, body mass index. 
Table 4 Regression analysis on BMI and measured depth of each point for male and female subjects

\begin{tabular}{|c|c|c|c|c|}
\hline & \multicolumn{2}{|l|}{ Male } & \multicolumn{2}{|l|}{ Female } \\
\hline & \multicolumn{2}{|c|}{ Regression coefficient } & \multicolumn{2}{|c|}{ Regression coefficient } \\
\hline & Intercept & BMI (95\% Cl) & Intercept & BMI (95\% Cl) \\
\hline GB21 (cm) & -1.16 & $0.31(0.26 \text { to } 0.35)^{\star *}$ & -1.80 & $0.31(0.28 \text { to } 0.34)^{\star \star}$ \\
\hline $\mathrm{SI} 14(\mathrm{~cm})$ & -0.25 & $0.28(0.22 \text { to } 0.33)^{\star *}$ & -0.99 & $0.26(0.23 \text { to } 0.29)^{\star \star}$ \\
\hline SI15 (cm) & 3.60 & $0.25(0.21 \text { to } 0.30)^{\star *}$ & 2.44 & $0.25(0.22 \text { to } 0.28)^{\star \star}$ \\
\hline GV15 (cm) & 2.12 & $0.13(0.11 \text { to } 0.16)^{\star *}$ & 0.72 & $0.17(0.15 \text { to } 0.19)^{\star \star}$ \\
\hline GV16 (cm) & 1.90 & $0.13(0.11 \text { to } 0.16)^{\star *}$ & 0.52 & $0.17(0.14 \text { to } 0.19)^{\star \star}$ \\
\hline GB20 (cm) & 3.01 & $0.10(0.07 \text { to } 0.13)^{\star *}$ & 1.43 & $0.14(0.12 \text { to } 0.16)^{\star \star}$ \\
\hline ST9 $(\mathrm{cm})$ & 0.46 & $0.06(0.04 \text { to } 0.07)^{\star *}$ & 0.03 & $0.07(0.06 \text { to } 0.08)^{\star \star}$ \\
\hline $\mathrm{SI} 16(\mathrm{~cm})$ & 0.77 & $0.05(0.03 \text { to } 0.07)^{\star *}$ & 0.30 & $0.07(0.05 \text { to } 0.08)^{\star *}$ \\
\hline $\mathrm{SI} 17(\mathrm{~cm})$ & 0.30 & $0.09(0.07 \text { to } 0.11)^{\star *}$ & -0.42 & $0.12(0.11 \text { to } 0.14)^{\star \star}$ \\
\hline TE16 (cm) & 0.61 & $0.12(0.09 \text { to } 0.14)^{\star *}$ & -1.06 & $0.18(0.15 \text { to } 0.20)^{\star \star}$ \\
\hline LI18 $(\mathrm{cm})$ & 0.68 & $0.03(0.02 \text { to } 0.04)^{\star *}$ & 0.10 & $0.05(0.04 \text { to } 0.06)^{\star *}$ \\
\hline
\end{tabular}

should be taken into consideration. Several studies revealed the difference in body fat distribution between the genders. They may partially explain the observed facts. Whittle et $a l^{49}$ pointed out that there was no clear correlation between the volume of soft tissue and fat in the neck region, especially when considering gender difference. Wells et $a l^{\tilde{D}^{0}}$ indicated that there are differences in terms of fat volume and distribution between adult males and females. There is also a sex difference in regional fat distribution. Women have more subcutaneous fat, whereas men have more visceral fat. ${ }^{51}$ So the depth in certain neck acupuncture points may not show significant difference, such as expected in the limbs or the chest region between different genders. ${ }^{35}$

Points with lesser mean values of measured depth such as SI16, SI17, SI18 and LI18, tend to have much less gender difference. Points of $\mathrm{GV}$ and $\mathrm{CV}$ tend to have less gender difference as well. ${ }^{35}$ The measured depths of points around the neck region were related to NC. Dancey et $a \bar{l}^{2}$ indicated that men had significantly larger NC than women, but the difference became much less pronounced when normalising NC to body height. This fact may reduce the gender difference to some extent. Another study also points out that there is an inverse association between upper airways size and both adiposity and visceral fat distribution in women, which means that obesity is not necessarily the only factor affecting the distance from skin to major vessels in the neck. ${ }^{53}$ In addition, females have smaller carotid arteries even after adjusting for body and neck size, age and blood pressure; this may also lead to an increase of the measured depth. ${ }^{54}$

All these facts may cause some disparity of measured depth in certain points between different genders and among different body sizes. Clinical practitioners should take more caution needling points having less gender difference. They could also refer to table 4 for predicted mean needling depth of each point as predicted by regression analysis.

\section{Limitations}

In this study, we were not able to analyse the depth difference by different ages and diagnoses. Very few studies mentioned the side difference. One study indicated that right side BL13 points seem to be deeper, especially in thinner people. ${ }^{35}$ BMI cut-off point for subject groupings may need further discussion, as may the question of whether or not to use FMI (fat mass index) or FFMI (fat-free mass index) rather than BMI.

We can also take the measurement of neck and/or waist girth into consideration, as it is a simple anthropometric measure and a good indicator of central obesity.

Measurement of more points at different regions of the body is undergoing and will be disclosed later.

Future study design may be improved by the following suggestions:

First, factors other than gender and BMI, such as age, body sides, diagnoses and different measuring methods should be controlled as much as possible. Second, prospective in vivo research is better than retrospective images or specimen dissections. Third, multicentre collaboration should be encouraged and fourth, the obtained needling depths can be compared with those documented in ancient writings.

\section{CONCLUSION}

Mean measured depths of 11 acupuncture points around the neck and shoulder region were obtained in different groups of participants classified according to BMI and sex. Participants with higher BMI had greater depths and males tended to have greater depths in most of the points. Clinical practitioners are recommended to consider this information to prevent complications when applying acupuncture treatment to their patients.

Contributors P-CC conceptualised the idea of using MRI to measure appropriate needling depth. P-CC and $\mathrm{H}-\mathrm{YC}$ were responsible for the study design, literature review, data collection and the writing of the manuscript. C-JH was responsible for the measurement of needling depth via MRI. Y-CH was responsible for the statistical analysis of the data and wrote the statistics part of the manuscript. J-GL was responsible for protocol modification. 
Funding This study is supported by China Medical University, Taichung Taiwan (CMU102-N-10), and in part by Taiwan Ministry of Health and welfare Clinical Trial and Research Center of Excellence (MOHW104-TDU-B-212-113002).

Competing interests None declared.

Ethics approval Tri-Service General Hospital, National Defense Medical Center Institutional Review Board.

Provenance and peer review Not commissioned; externally peer reviewed.

Data sharing statement Extra data can be accessed via the Dryad data repository at http://datadryad.org/ with the doi:10.5061/dryad.v2j00.

Open Access This is an Open Access article distributed in accordance with the Creative Commons Attribution Non Commercial (CC BY-NC 4.0) license, which permits others to distribute, remix, adapt, build upon this work noncommercially, and license their derivative works on different terms, provided the original work is properly cited and the use is non-commercial. See: http:// creativecommons.org/licenses/by-nc/4.0/

\section{REFERENCES}

1. Witt CM, Pach D, Brinkhaus B, et al. Safety of acupuncture: results of a prospective observational study with 229,230 patients and introduction of a medical information and consent form. Forsch Komplementmed 2009;16:91-7.

2. White A. A cumulative review of the range and incidence of significant adverse events associated with acupuncture. Acupunct Med 2004;22:122-33.

3. Ernst E. Fatalities after CAM: an overview. Br J Gen Pract 2011;61:404-5.

4. MacPherson $\mathrm{H}$, Thomas $\mathrm{K}$. Short term reactions to acupuncture-a cross-sectional survey of patient reports. Acupunct Med 2005;23:112-20.

5. Macpherson $\mathrm{H}$, Scullion A, Thomas KJ, et al. Patient reports of adverse events associated with acupuncture treatment: a prospective national survey. Qual Saf Health Care 2004;13:349-55.

6. Lee SW, Ahn JY, Choi WJ, et al. A needle penetrating the stomach cavity after acupuncture. Clin Endosc 2014;47:258-61.

7. Lee JH, Lee H, Jo DJ. An acute cervical epidural hematoma as a complication of dry needling. Spine (Phila Pa 1976) 2011;36:E891-3.

8. Eftekhar B, Ketabchi E, Ghodsi M, et al. Lumbar epidural hematoma due to lumbar acupunctures. Neurol India 2005;53:245-6.

9. Chen JC, Chen Y, Lin SM, et al. Acute spinal epidural hematoma after acupuncture. J Trauma 2006;60:414-16; discussion 16.

10. Conway N, Sreenivasan S. The acupunctured lung. Am J Emerg Med 2014;32:111.e1.

11. Tagami R, Moriya T, Kinoshita K, et al. Bilateral tension pneumothorax related to acupuncture. Acupunct Med 2013;31:242-4.

12. Ding M, Qiu Y, Jiang Z, et al. Acupuncture-associated pneumothorax. J Altern Complement Med 2013;19:564-8.

13. Su JW, Lim CH, Chua YL. Bilateral pneumothoraces as a complication of acupuncture. Singapore Med J 2007;48:e32-3.

14. Lao L, Hamilton GR, Fu J, et al. Is acupuncture safe? A systematic review of case reports. Altern Ther Health Med 2003;9:72-83.

15. Peuker ET, White A, Ernst E, et al. Traumatic complications of acupuncture. Therapists need to know human anatomy. Arch Fam Med 1999;8:553-8.

16. Norheim AJ. Adverse effects of acupuncture: a study of the literature for the years 1981-1994. J Altern Complement Med 1996;2:291-7.

17. Lao L. Safety issues in acupuncture. J Altern Complement Med 1996;2:27-31.

18. Song BG, Park JR. Acupuncture needles over the myocardium. Heart Lung Circ 2010;19:480.

19. Chun KJ, Lee SG, Son BS, et al. Life-threatening cardiac tamponade: a rare complication of acupuncture. J Cardiothorac Surg 2014;9:61.

20. Lee DG, Lee SH, Hwang SW, et al. Myositis ossificans in the paraspinal muscles of the neck after acupuncture: a case report. Spine J 2013;13:e9-e12.

21. Wong $\mathrm{YM}$, Hobara $\mathrm{H}$. Hand acupuncture and vascular injury J Nippon Med Sch 2012;79:246-7.

22. Kuo HF, Shih MC, Kao WP, et al. Acupuncture-induced popliteal arteriovenous fistula successfully treated with percutaneous endovascular intervention. Kaohsiung J Med Sci 2010;26:158-62.

23. Onda $\mathrm{K}$, Honda $\mathrm{H}$, Arai $\mathrm{H}$, et al. [Dissociated sensory loss caused by acupuncture injury to the cervical spinal cord]. Brain Nerve 2008;60:1187-90.

24. Choo DC, Yue G. Acute intracranial hemorrhage caused by acupuncture. Headache 2000;40:397-8.
25. Chen CY, Liu GC, Sheu RS, et al. Bacterial meningitis and lumbar epidural hematoma due to lumbar acupunctures: a case report Kaohsiung J Med Sci 1997;13:328-31.

26. Ilhan A, Alioglu Z, Adanir M, et al. Transverse myelopathy after acupuncture therapy: a case report. Acupunct Electrother Res 1995;20:191-4

27. Yu HJ, Lee KE, Kang HS, et al. Teaching Neurolmages: multiple epidural abscesses after acupuncture. Neurology 2013;80:e169.

28. Lee JH, Cho JH, Jo DJ. Cervical epidural abscess after cupping and acupuncture. Complement Ther Med 2012;20:228-31.

29. Yazawa S, Ohi T, Sugimoto S, et al. Cervical spinal epidural abscess following acupuncture: successful treatment with antibiotics. Intern Med 1998;37:161-5.

30. Bang MS, Lim SH. Paraplegia caused by spinal infection after acupuncture. Spinal Cord 2006;44:258-9.

31. Daivajna S, Jones A, O'Malley $M$, et al. Unilateral septic arthritis of a lumbar facet joint secondary to acupuncture treatment--a case report. Acupunct Med 2004;22:152-5.

32. Chen $\mathrm{MH}$, Chen $\mathrm{MH}$, Huang JS. Cervical subdural empyema following acupuncture. J Clin Neurosci 2004;11:909-11.

33. Ha KY, Kim YH. Chronic inflammatory granuloma mimics clinical manifestations of lumbar spinal stenosis after acupuncture: a case report. Spine (Phila Pa 1976) 2003;28:E217-20.

34. Ernst E. Deaths after acupuncture: a systematic review. Int J Risk Saf Med 2010;22:131-6.

35. Chou PC, Chu HY, Lin JG. Safe needling depth of acupuncture points. J Altern Complement Med 2011;17:199-206.

36. $\mathrm{Li} \mathrm{X}, \mathrm{Ye} Z$. Magnetic resonance imaging features of alveolar soft part sarcoma: report of 14 cases. World J Surg Oncol 2014;12:36.

37. Anuurad E, Shiwaku K, Nogi A, et al. The new BMI criteria for Asians by the regional office for the western pacific region of $\mathrm{WHO}$ are suitable for screening of overweight to prevent metabolic syndrome in elder Japanese workers. J Occup Health 2003;45:335-43.

38. Organization WH. WHO Standard Acupuncture Point Locations in the Western Pacific Region. 2008.

39. Dirix $P$, Haustermans $K$, Vandecaveye $V$. The value of magnetic resonance imaging for radiotherapy planning. Semin Radiat Oncol 2014;24:151-9.

40. Totty WG, Murphy WA, Lee JK. Soft-tissue tumors: MR imaging. Radiology 1986;160:135-41.

41. Sundaram M. MR imaging of soft tissue tumors: an overview. Semin Musculoskelet Radiol 1999;3:15-20.

42. Petasnick JP, Turner DA, Charters JR, et al. Soft-tissue masses of the locomotor system: comparison of MR imaging with CT. Radiology 1986;160:125-33.

43. Mei Z, Grummer-Strawn LM, Pietrobelli A, et al. Validity of body mass index compared with other body-composition screening indexes for the assessment of body fatness in children and adolescents. Am J Clin Nutr 2002;75:978-85.

44. Komiya $\mathrm{H}$, Masubuchi $\mathrm{Y}$, Mori $\mathrm{Y}$, et al. The validity of body mass index criteria in obese school-aged children. Tohoku J Exp Med 2008;214:27-37.

45. Groenemeyer DH, Zhang L, Schirp S, et al. Localization of acupuncture points BL25 and BL26 using computed tomography. $J$ Altern Complement Med 2009;15:1285-91.

46. Ben-Noun L, Sohar E, Laor A. Neck circumference as a simple screening measure for identifying overweight and obese patients. Obesity Res 2001;9:470-7.

47. Onat $A$, Hergenc $G$, Yuksel $H$, et al. Neck circumference as a measure of central obesity: associations with metabolic syndrome and obstructive sleep apnea syndrome beyond waist circumference. Clin Nutr 2009;28:46-51.

48. O'Donnell DE, Deesomchok A, Lam YM, et al. Effects of BMI on static lung volumes in patients with airway obstruction. Chest 2011;140:461-8.

49. Whittle AT, Marshall I, Mortimore IL, et al. Neck soft tissue and fat distribution: comparison between normal men and women by magnetic resonance imaging. Thorax 1999;54:323-8.

50. Wells JC. Sexual dimorphism of body composition. Best Pract Res Clin Endocrinol Metab 2007;21:415-30.

51. Nedungadi TP, Clegg DJ. Sexual dimorphism in body fat distribution and risk for cardiovascular diseases. J Cardiovasc Transl Res 2009;2:321-7.

52. Dancey DR, Hanly PJ, Soong C, et al. Gender differences in sleep apnea: the role of neck circumference. Chest 2003;123:1544-50.

53. Busetto L, Calo E, Mazza M, et al. Upper airway size is related to obesity and body fat distribution in women. Eur Arch Otorhinolaryngol 2009;266:559-63.

54. Krejza J, Arkuszewski M, Kasner SE, et al. Carotid artery diameter in men and women and the relation to body and neck size. Stroke 2006;37:1103-5. 